\title{
Analisa "In Silico" Gen Kakao (Theobroma cacao L.) yang Terlibat dalam Sistem Ketahanan Terhadap Hama dan Penyakit
}

\section{("In Silico" Analysis of Cacao (Theobroma cacao L.) Genes that Involved in Pathogen and Disease Resistance Mechanisms)}

\author{
Muhammad Budi Agung $^{1 *}$, I Made Budiarsa ${ }^{2}$, dan I Nengah Suwastika ${ }^{1 *}$ \\ ${ }^{1}$ Lab. Bioteknologi Jur. Biologi Fakultas MIPA, Universitas Tadulako \\ ${ }^{2}$ Prodi Biologi Jur. Pendidikan MIPA Fakultas Keguruan dan Ilmu Pendidikan, Universitas Tadulako
}

\begin{abstract}
Cocoa bean is one of the main commodities in the world, which still have problem regarding yield degradation due to pathogens and disease attack. Developing robust cacao plant that genetically resistant to pathogen and disease attack is an ideal solution in over taking on this problem. The aim of this study was to identify Theobroma cacao genes on database of cacao genome that homolog to resistance genes in other plant, through in silico analysis. Basic information survey and gene identification was performed in GenBank and The Arabidopsis Information Resource database. In silico analysis contains protein BLAST, homology test of each gene's protein candidates, and identification of homologue gene in Cacao Genome Database using data source "Theobroma cacao cv. Matina 1-6 v1.1" genome. Identification results that Thecc1EG006332t1 (PR-1), Thecc1EG024509t1 (PR-2), Thecc1EG024514t1 (PR-2), Thecc1EG026942t1 (CTL1), Thecc1EG021326t1 (CTL1), and Thecc1EG033984t1 (PR-5) gene of Cacao Genome Database are Theobroma cacao genes that homolog to plant's resistance genes, which highly possible to have similar functions of each gene's homologue gene.
\end{abstract}

Keywords: in silico, cacao, model plant, resistance gene, pathogen and disease, homologue, BLAST, phylogenetic tree.

\begin{abstract}
ABSTRAK
Biji kakao adalah salah satu komoditas utama di dunia yang hingga saat ini masih memiliki masalah penurunan produksi yang mayoritas disebabkan oleh serangan hama dan penyakit. Mengembangkan kultivar kakao yang secara genetik tahan terhadap serangan hama dan penyakit adalah salah satu solusi yang ideal dalam mengatasi permasalahan tersebut. Penelitian ini bertujuan untuk mengetahui gen-gen Theobroma cacao pada database genom kakao yang homolog dengan gen yang terlibat dalam sistem ketahanan terhadap hama dan penyakit pada tumbuhan lain melalui analisis in silico. Survei informasi dasar dan identifikasi gen yang terlibat dalam sistem ketahanan tumbuhan model Arabidopsis thaliana dan Oryza
\end{abstract}

Corresponding Authors: muh_budiagung@yahoo.com(MBA), isuwastika@yahoo.com.au (INS) 
sativa dilakukan pada GenBank dan The Arabidopsis Information Resource. Analisa in silico yang dilakukan berupa BLAST urutan protein, uji homologi protein kandidat masing-masing gen, dan identifikasi gen homolog pada Cacao Genome Database menggunakan sumber data genom "Theobroma cacao cv. Matina 1-6 v1.1". Berdasarkan hasil identifikasi, gen Thecc1EG006332t1 (PR-1), Thecc1EG024509t1 (PR-2), Thecc1EG024514t1 (PR-2), Thecc1EG026942t1 (CTL1), Thecc1EG021326t1 (CTL1), dan Thecc1EG033984t1 (PR-5) pada Cacao Genome Database (CGD) adalah gen Theobroma cacao yang homolog dengan gen yang terlibat dalam sistem ketahanan tumbuhan terhadap hama dan penyakit, serta kemungkinan besar memiliki fungsi yang sama dengan gen homolognya masing-masing.

Kata Kunci : in silico, kakao, tumbuhan model, gen ketahanan, hama dan penyakit, homolog, BLAST, pohon filogenetik.

\section{LATAR BELAKANG}

Sistem ketahanan tumbuhan terhadap hama dan penyakit telah banyak dipelajari pada berbagai tumbuhan, antara lain Arabidopsis thaliana (L.) Heynh dan Oryza sativa, namun informasi pada Theobroma cacao L. masih terbatas.

Serangan hama dan penyakit adalah tantangan utama dalam budidaya kakao. Setiap tahun kehilangan hasil panen kakao di seluruh dunia diperkirakan sebanyak 30$40 \%$ oleh hal tersebut (Cudjoe, 2013). Pengembangan kultivar kakao yang secara genetik tahan terhadap serangan hama dan penyakit adalah salah satu solusi yang ideal dalam mengatasi permasalahan tersebut.

Genom T. cacao telah diurut basa nukleotidanya sebesar hampir $80 \%$ dari perkiraan besar genom kakao kultivar "Matina 1-6" dan dapat diakses secara bebas oleh publik (Motamayor et al., 2013). Ketersediaan informasi ini dapat memudahkan dalam studi kakao tentang gen-gen yang terlibat dalam sistem ketahanan terhadap hama dan penyakit.

Tumbuhan merespon infeksi patogen dengan menginduksi hypersensitive response (HR) (Baker et al., 1997) yang berlangsung pada sel atau jaringan yang terinfeksi (Ryals et al., 1996). Tumbuhan mengawali proses ini dengan mengenali gen patogen (avirulence) oleh gen resistan yang dimiliki oleh tumbuhan (Baker et al., 1997).

Setelah infeksi patogen, sistem ketahanan tumbuhan hypersensitive response (HR) atau systemic acquired resistance (SAR) akan memicu asam salisilat terakumulasi di dalam sel dan menyebabkan pengaktifan gen NPR1.

Protein PR-1 memiliki aktifitas anti fungi (oomycete) (Alexander et al., 1993 dan Niderman et al., 1995). Peningkatan ekspresi protein PR-1 terjadi pada bagian pada tumbuhan yang tidak terinfeksi ketika serangan patogen berlangsung (Van Loon et al., 2006). Peningkatan ekspresi dari 
protein PR-1 juga dipicu oleh penurunan tingkat regulasi dari B-1,3-glucanase (Riviere et al., 2008).

\section{ß-1,3-glucanase}

(PR-2) dan chitinase adalah protein yang bersinergi dalam sistem ketahanan tumbuhan, terutama terhadap serangan fungi (Ebrahim et al., 2011). Kedua protein ini juga memperlihatkan respon terhadap serangan patogen lainnya, elisitor, dan etilen (hormon stress tumbuhan) (Boller et al., 1983).

Substrat dari protein chitinase adalah kitin, yaitu salah satu penyusun dalam dinding sel fungi dan eksoskeleton dari artropoda (Bartnicki-Garcia, 1968), serta terdapat pada bakteria, hewan, dan sebagian besar di bagian daun pada tumbuhan (Ebrahim et al., 2011). Chitinase memiliki isoform yang masing-masing bereaksi terhadap patogen yang spesifik (Sela-Buurlage et al., 1993; dan Yeh et al., 2000). Sedangkan substrat pada B-1,3glucanase (PR-2) adalah B-1,3-glucan, yaitu salah satu komponen utama dinding sel pada fungi yang patogenik (Wessels dan Sietsma, 1981; dan Adams, 2004). Gen ini juga menunjukkan efek pada sistem ketahanan tumbuhan secara tidak langsung dengan cara memicu pembentukan formasi elisitor oligosakarida, dimana elisitor tersebut memicu produksi protein PR yang lain atau senyawa anti fungi dengan berat molekul yang rendah (Keen dan Yoshikawa, 1983; Ham et al., 1991; dan Klarzynski et al., 2000).

PR-5 adalah gen yang mengkode protein yang disebut dengan protein thaumatin-like, karena memiliki kemiripian urutan yang tinggi dengan protein thaumatin (Kitajima dan Sato, 1999). Ekspresi dari PR-5 pada A. thaliana merupakan respon dari induksi asam salisilat dan NA (Zhang et al., 2010). Hasil analisis menunjukkan bahwa PR-5 memiliki aktifitas anti fungi, antara lain lisis spora, inhibisi pertumbuhan hifa, dan mengurangi perkecambahan spora (Woloshuk et al., 1991; Abad et al., 1996; dan Koiwa et al., 1997).

\section{Saat ini, Cacao Genome Database} telah diperkenalkan dengan perkiraan terdapat 35.000 gen pada genom T. cacao kultivar Matina $1-6$ (http://www.cacaogenomedb.org/). Namun, anotasi masing-masing gen masih belum terselesaikan. Berdasarkan informasi yang tersedia pada database yang ada serta pentingnya identifikasi gen yang terlibat dan sistem pertahanan tubuh tumbuhan terhadap serangan hama dan penyakit tumbuhan, maka sangat penting untuk dilakukan analisa in silico guna mengetahui gen-gen homolog pada genom T. cacao berdasarkan informasi yang ada pada tumbuhan model A. thaliana. 


\section{BAHAN DAN METODE}

\section{Survei Informasi Dasar Gen Resistan}

Tumbuhan Model. Gen resistan (PR-1, PR-2, PR-2, CTL1, dan PR-5) Arabidopsis thaliana diakses pada database GenBank (www.ncbi.nlm.nih.gov). Urutan DNA, mRNA, dan protein dari masing-masing gen tersebut diunduh dalam format “GenBank (Full)". Kemudian dilakukan uji transkripsi-translasi

(DNA $\rightarrow$ mRNA $\rightarrow$ protein) menggunakan program ClustalW dan Restriction Map pada software BioEdit (Hall, 1999). Identifikasi urutan DNA, mRNA, dan protein masing-masing gen dilakukan pada database The Arabidopsis Information Resource (www.arabidopsis.org) menggunakan fitur GBrowse. Protein dari masing-masing gen dianalisa famili, domain, dan motifnya menggunakan layanan InterPro (www.ebi.ac.uk/interpro) (Quevillon et al., 2005).

\section{Mencari Gen Homolog menggunakan}

BLAST. BLAST protein (Altschul et al., 1990) dilakukan pada database NCBI (www.ncbi.nlm.nih.gov) terhadap genom Theobroma cacao dan Oryza sativa. Protein teratas hasil BLAST dengan skor yang tinggi dipilih sebagai protein kandidat, kemudian diunduh dalam format file "GenBank (complete sequence)".

\section{Uji Homologi Masing-masing Protein}

Kandidat. Protein masing-masing gen beserta protein kandidat homolognya disejajarkan menggunakan program ClustalW pada software BioEdit dengan matriks kemiripan "BLOSUM62" (Henikoff dan Henikoff, 1992). Hasil pensejajaran (alignment) disimpan dalam format file ".fas". File alignment tersebut kemudian digunakan untuk konstruksi pohon filogenetik menggunakan software MEGA 6 (Tamura et al., 2013). Pohon filogenetik dikonstruksi menggunakan metode Maximum Likelihood, model subtitusi "Dayhoff Method", perlakuan terhadap gap dan missing data "Partial deletion", dan 500 kali bootstrap. Kandidat protein homolog pada pohon filogenetik yang terdekat dengan protein Arabidopsis thaliana dianalisa menggunakan layanan InterPro (www.ebi.ac.uk/interpro).

\section{Identifikasi Gen Homolog pada Cacao}

Genome Database. Gen homolog gen resistan (PR-1, PR-2, PR-5, dan CTL1) A. thaliana diakses pada database GenBank (www.ncbi.nlm.nih.gov). Urutan DNA, mRNA, dan protein dari masing-masing gen tersebut diunduh dalam format "GenBank (Full)". Identifikasi urutan DNA, mRNA, dan protein masing-masing gen homolog dilakukan pada database Cacao Genome Database (www.cacaogenomedb.org) menggunakan 
fitur GBrowse dengan sumber data yaitu genom "Theobroma cacao cv. Matina 1-6 v1.1" (Motamayor et al., 2013). Protein dari masing-masing gen homolog diidentifikasi keberadaan dari motif yang telah diperoleh sebelumnya.

\section{HASIL}

Analisa Protein pada InterPro. Protein Arabidopsis thaliana yang dianalisa adalah NP_179068.1 (PR-1), NP_191285.1 (PR2), NP_199025.1 (BG_PPAP), NP_172076.1 (CTL1), dan NP_177641.1 (PR-5). Hasil analisa menunjukkan seluruh protein ditemukan motif proteinnya. Hasil dari analisa protein tersebut disajikan pada tabel 1 .

Tabel 1. Hasil analisa protein resistan Arabidopsis thaliana pada InterPro.

\begin{tabular}{ccc}
\hline Nama gen & Motif & Posisi \\
\hline \multirow{2}{*}{ PR-1 } & CRISP 1 & $119-129$ \\
& CRISP 2 & $145-155$ \\
& CRISP 3 & $38-42$ \\
& CRISP 4 & $80-83$ \\
PR-2 & GLYCOSYL HYDROLtida & $160-161$ \\
\hline \multirow{3}{*}{ CTL1 } & CHITINASE_19_1 & 258-270 \\
& CHITINASE_19_2 & $211-221$ \\
\hline PR-5 & THAUMATIN_1 & $86-99$ \\
\hline Protein
\end{tabular}

Protein PR-1 memiliki motif CRISP 1

(GHYTQVVWRKS), $\quad$ CRISP 2 (IISCNYDPRGN), CRISP 3 (HNQAR), CRISP 4 (GENL), dan PY dipeptida seperti yang dijelaskan pada Gibbs et al. (2008); protein PR-2 memiliki motif GLYCOSYL HYDROL 17 (LEIVVSETGWPTEG); protein PR-5 memiliki motif THAUMATIN_1 (GNGRCVTGDCGGL RC); dan CTL1 memiliki motif CHITINASE_19_1

(AHAVGFWDYQSFITAA ALFEPLGDG) dan

CHITINASE_19_2

(LAFQAAIWRWMT). Hasil identifikasi motif pada protein PR1, PR2, dan PR5 menunjukkan bahwa pola motif masingmasing protein sesuai dengan urutan asam aminonya, sedangkan pada protein CTL1 terdapat beberapa perbedaan. Pada motif CHITINASE_19_1 protein CTL1 tingkat kesamaan urutan asam amino terhadap pola motifnya adalah $79,1 \%$, dimana residu cysteine tersubtitusi dengan alanine (81); tyrosine tersubtitusi dengan tryptophan (87); serinelthreonine tersubtitusi dengan aspartic acid (88); dan diantara proline (101) dan phenylalanine (104) tersisip residu leucine (102) dan glycine (103) yang diduga disebabkan oleh mutasi berupa insertion-deletion (Hsing dan Cherkasov, 2008). Sedangkan pada motif CHITINASE_19_2 tingkat kesamaannya adalah 90,91\%, dimana residu phenylalaninel tyrosine tersubtitusi dengan arginine (219).

Motif yang digunakan dalam identifikasi protein-protein tersebut akan digunakan 
selanjutnya dalam tahap pensejajaran (menyusun alignment) dan identifikasi protein homolog.

Alignment Protein. Alignment ditampilkan dengan shading threshold 95\%. Alignment telah dimodifikasi dengan menghilangkan daerah yang mengandung banyak gap seperti yang dijelaskan pada Claverie dan Notredame (2007). Kemiripan yang cukup tinggi terlihat pada masing-masing alignment, yang ditunjukkan dengan adanya masing-masing motif pada protein PR-1, PR-2, CTL1, dan PR-5, serta daerah conserved yang cukup luas yang ditunjukkan pada Gambar 1-4. Pada gambar-gambar tersebut, protein $A$. thaliana ditandai dengan awalan nama "[At]", T. cacao ditandai dengan awalan nama "[Tc]", dan $O$. sativa ditandai dengan awalan nama "[Os]".

Pohon Filogenetik. Hasil konstruksi pohon filogenetik metode Maximum Likelihood menunjukkan tingkat kemiripan antar protein. Dari konstruksi pohon filogenetik, diperoleh hasil bahwa; protein XP_007041422.1 dan XP_007008873.1 homolog terhadap protein PR-1 A. thaliana; protein XP_007028619.1 dan XP_007028622.1 homolog terhadap protein PR-2 A. thaliana; protein XP_007022927.1 dan XP_007035746.1 homolog terhadap protein CTL1 A. thaliana; dan protein
XP_007017454.1 homolog terhadap protein PR-5 A. thaliana. Hasil konstruksi pohon filogenetik selengkapnya ditunjukkan pada gambar 5.

\section{Analisa Protein Homolog pada InterPro.} Masing-masing protein homolog dianalisa pada InterPro untuk memastikan kesamaan karakteristik terhadap protein modelnya (protein resistan pada A. thaliana). Hasil dari analisa protein menunjukkan bahwa semua protein memiliki karakteristik yang sama dengan protein modelnya, kecuali pada protein XP_007008873.1 yang memiliki karakter yang berbeda dengan protein PR-1 Arabidopsis thaliana, sehingga digugurkan sebagai homolog dari protein tersebut. 


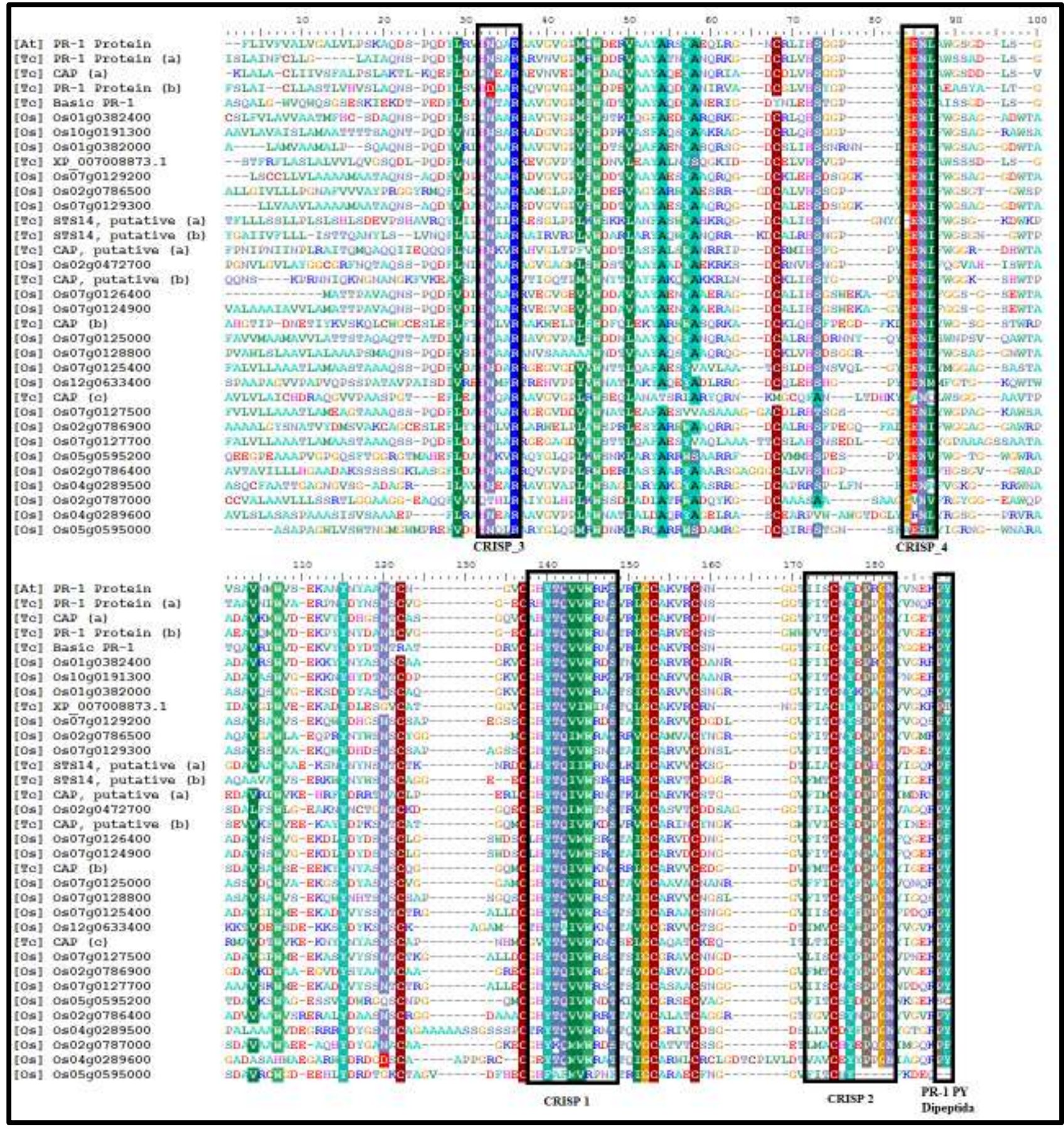

Gambar 1. Alignment protein PR-1 A. thaliana dengan 30 protein kandidat homolognya yang berasal dari genom T. cacao dan O. sativa. Terdapat motif khas protein PR-1 yaitu CRISP 1, CRISP 2, CRISP 3, CRISP 4, dan PR-1 PY dipeptida yang ditandai dengan kotak berwarna hitam, sedangkan daerah conserved ditandai dengan latar belakang asam amino yang diwarnai 


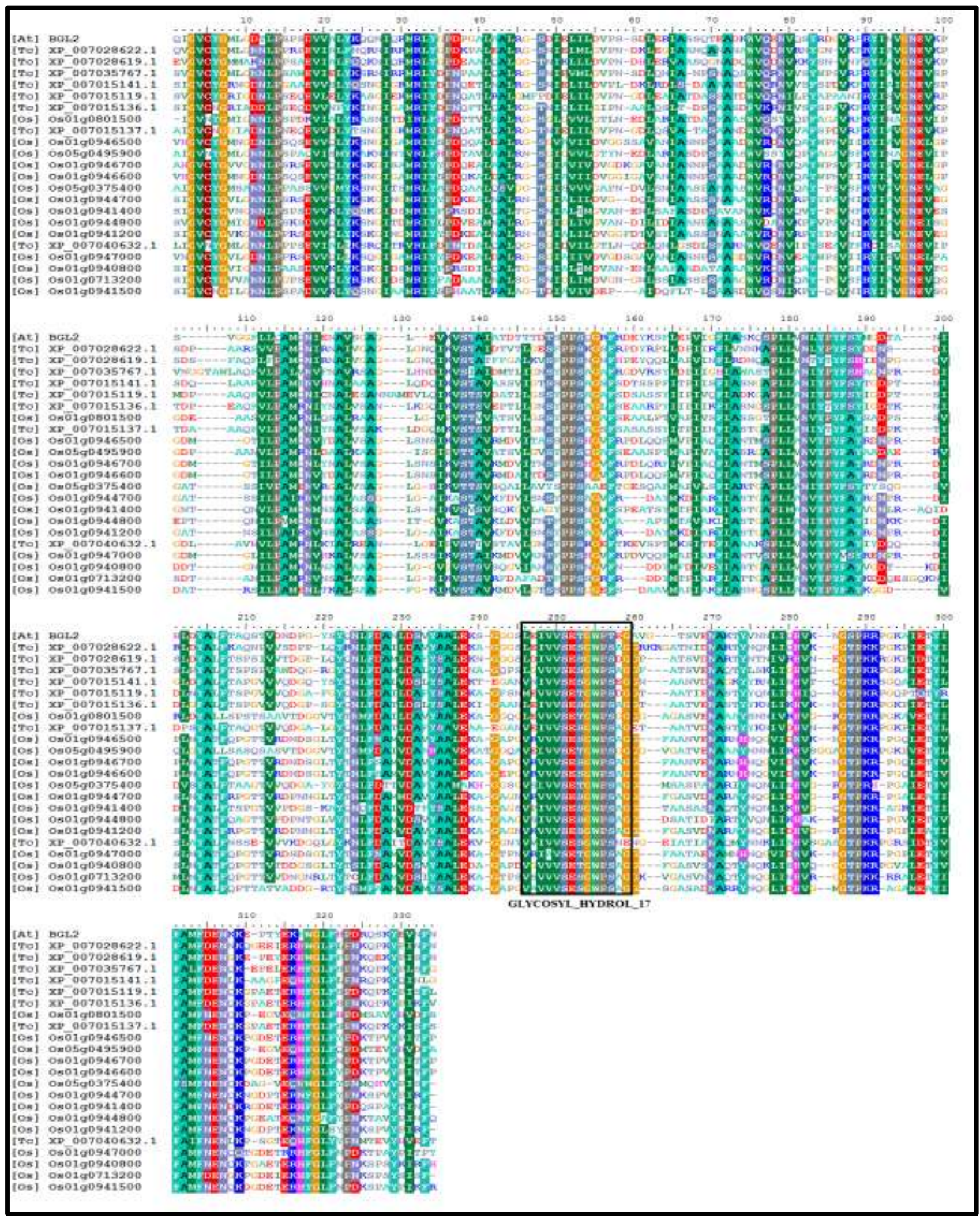

Gambar 2. Alignment protein PR-2 A. thaliana dengan 22 protein kandidat homolognya yang berasal dari genom $T$. cacao dan $O$. sativa. Terdapat motif khas protein PR-2 yaitu GLYCOSYL_HYDROL_17 yang ditandai dengan kotak berwarna hitam, sedangkan daerah conserved ditandai dengan latar belakang asam amino yang diwarnai

\section{Analisa "In Silico" Gen Kakao (Theobroma cacao L.) yang Terlibat dalam Sistem Ketahanan Terhadap Hama dan Penyakit}

(Muhammad Budi Agung dkk) 


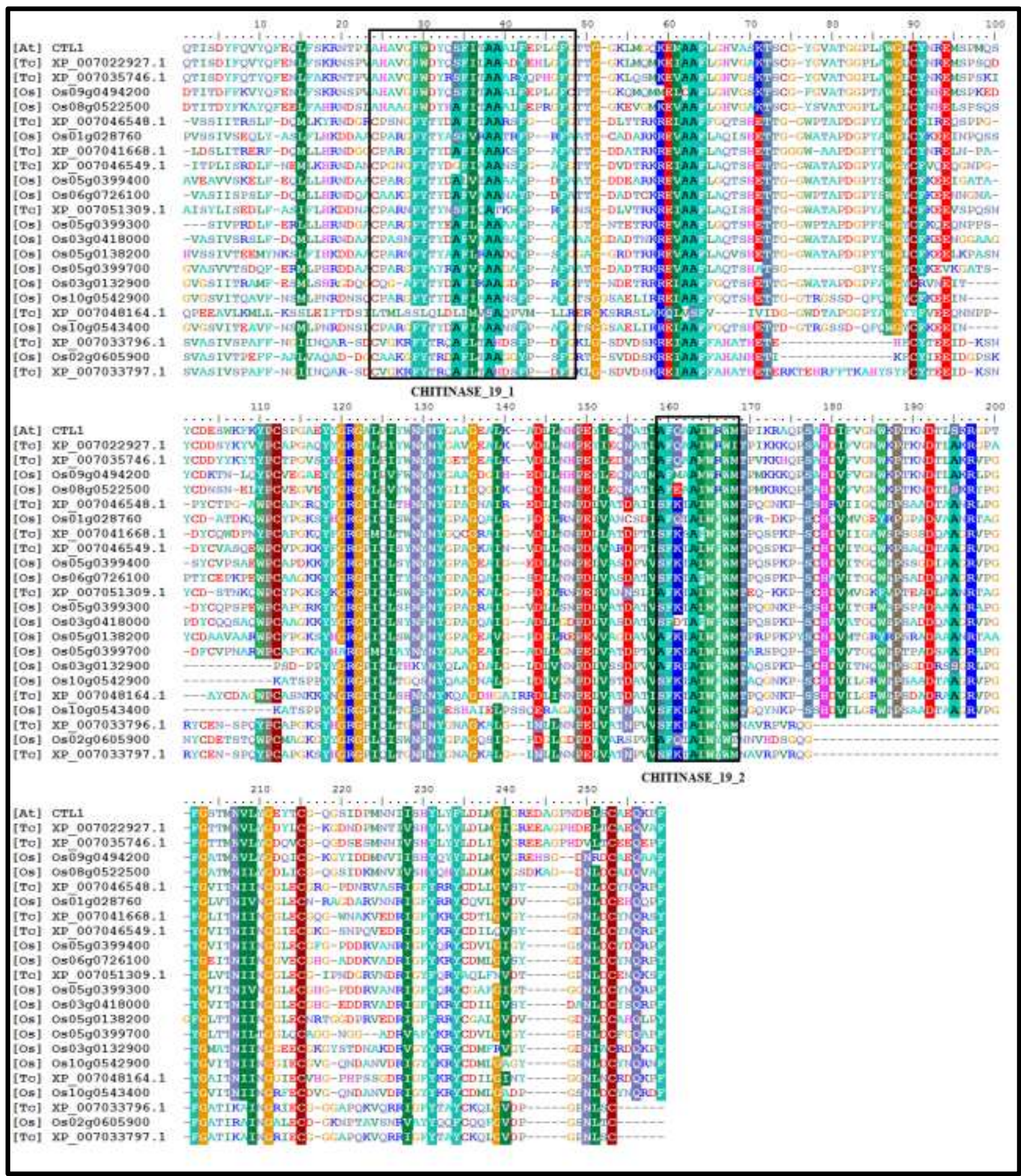

Gambar 3. Alignment protein CTL1 A. thaliana dengan 22 protein kandidat homolognya yang berasal dari genom $T$. cacao dan $O$. sativa. Terdapat motif khas protein CTL1 yaitu CHITINASE_19_1 dan CHITINASE_19_2 yang ditandai dengan kotak berwarna hitam, sedangkan daerah conserved ditandai dengan latar belakang asam amino yang diwarnai

\author{
Analisa "In Silico" Gen Kakao (Theobroma cacao L.) yang Terlibat dalam Sistem \\ Ketahanan Terhadap Hama dan Penyakit \\ (Muhammad Budi Agung dkk)
}


[To] XP 007017454.1

[Tol XD_007046.679.1

[Te] XP- $\mathrm{XP}^{-} 00704884$.

[Os] Os 0 3g0233200
[Te] XP 007041885

[Tel XP_007041885.1

[To] XD 007041882.1

[To] XP_007036794.1

[To] XD_007046683,1

[To] XP_007027491.1

[To] XP 007017824.1

[Fel XP_-007027490.1

$[\mathrm{To}] \mathrm{XP}, 007027494$.
[Os] Os04g0689900

[Os] Os06g0691200
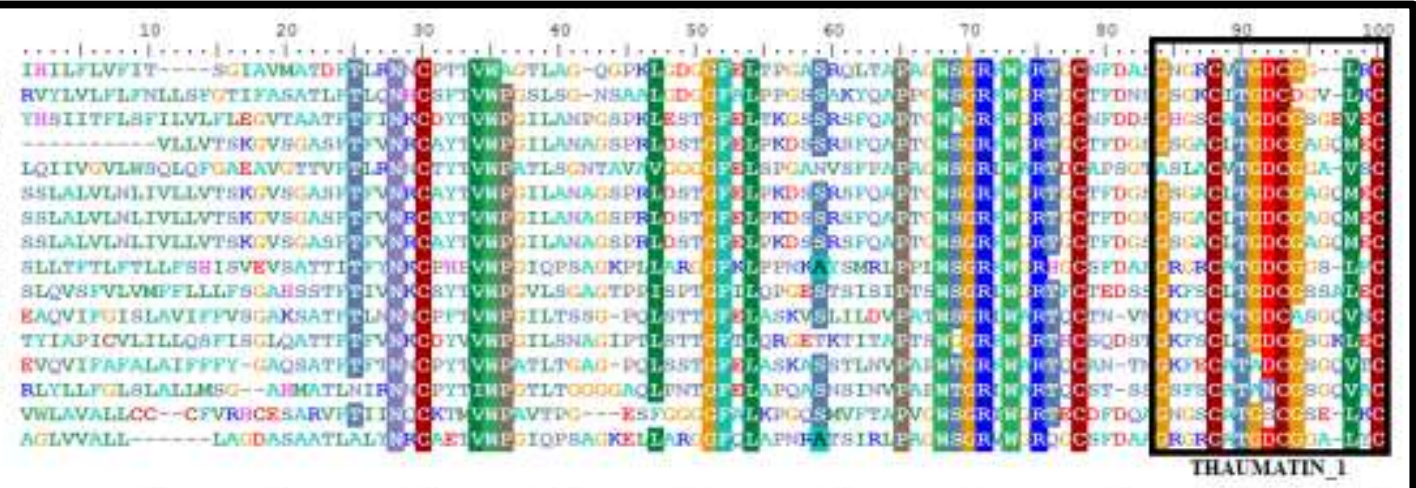

At] PR5

[Ta] XP 007017454.1

[To] XP 007046679.1

[To] XP 007041884,1

[Os] Os0̄3g0233200

[To] XP_007041885.1

[To] XP- 007041883.1

[To1 XP- ${ }^{-} 0070418 B 2.1$

[To] XP-007036794, 1

[Te] XP- 007046683.1

[To] Xe- 007027491.1

[To] XD 007017824.1

[To] XP_-007027490.1

$[\mathrm{TO}] \mathrm{XP}-007027494.1$

[Os] Os0ี4g0689900

[Os] Os06g0691200

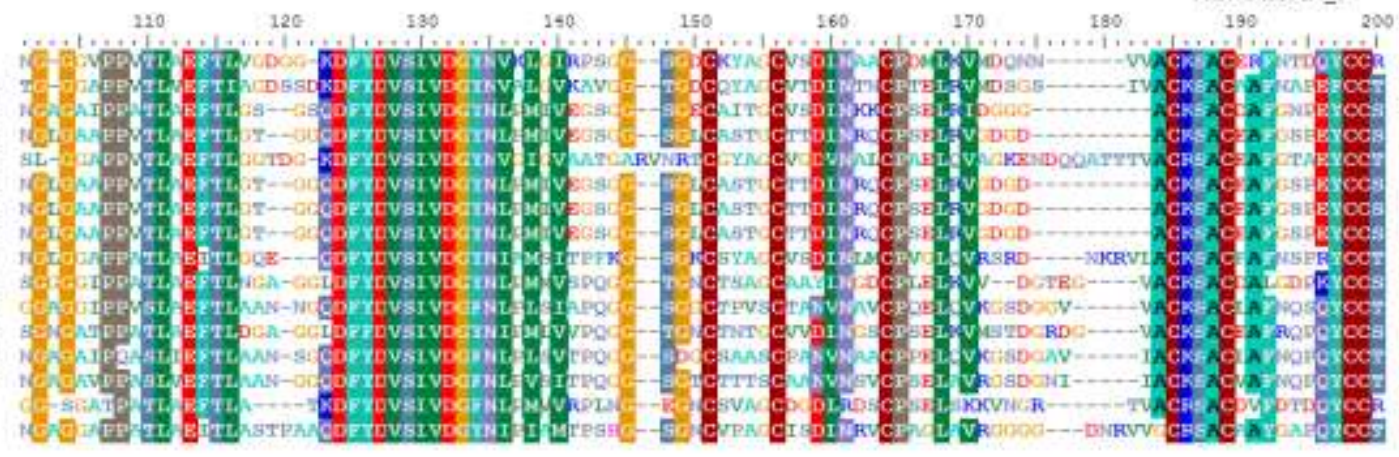

[At] Pis

[Te] XP 007046579.1

[To] $\mathrm{XP}^{-} 007041884,1$

[Os] Os03 390233200

$[\mathrm{TO}] \mathrm{XP}, 007041885,1$

[To] XD 007041833.1

[To] XP-007041882-1

[To] XP 007036794.1

[To] XD 007046683,1

$[\mathrm{TO}] \mathrm{XP}$ 007027491.1

TTOI XD 007017824.1

[Tol XP-007027490.1

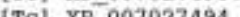

[To

[Os] Os04g0689900
[Os] Os:06g0691200

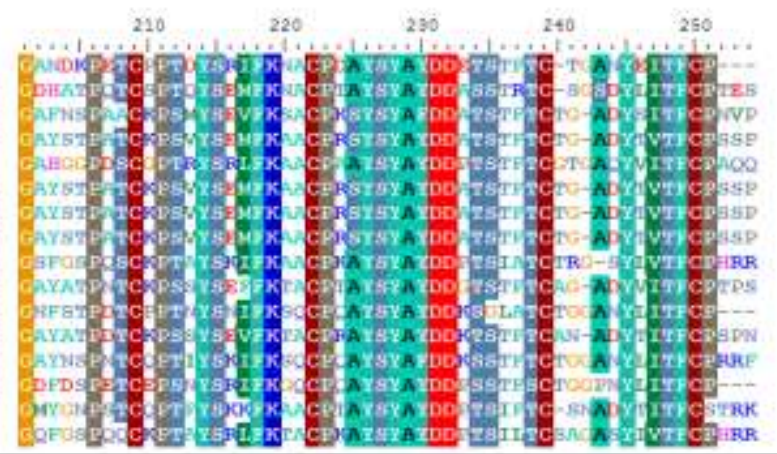

Gambar 4. Alignment protein PR-5 A. thaliana dengan 15 protein kandidat homolognya yang berasal dari genom $T$. cacao dan $O$. sativa. Terdapat motif khas protein PR-5 yaitu THAUMATIN_1 yang ditandai dengan kotak berwarna hitam, sedangkan daerah conserved ditandai dengan latar belakang asam amino yang diwarnai 


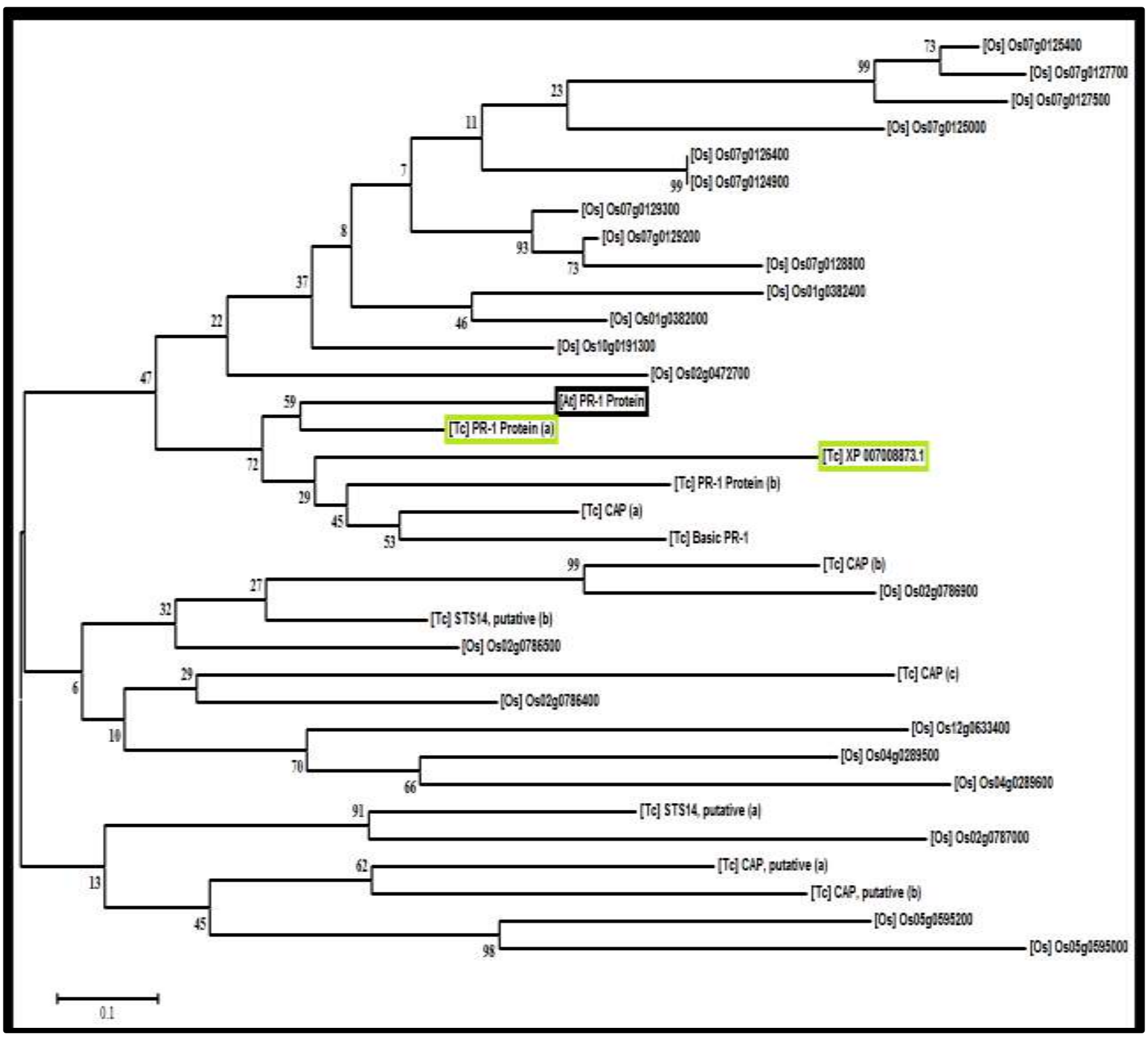

Analisa "In Silico" Gen Kakao (Theobroma cacao L.) yang Terlibat dalam Sistem Ketahanan Terhadap Hama dan Penyakit (Muhammad Budi Agung dkk) 


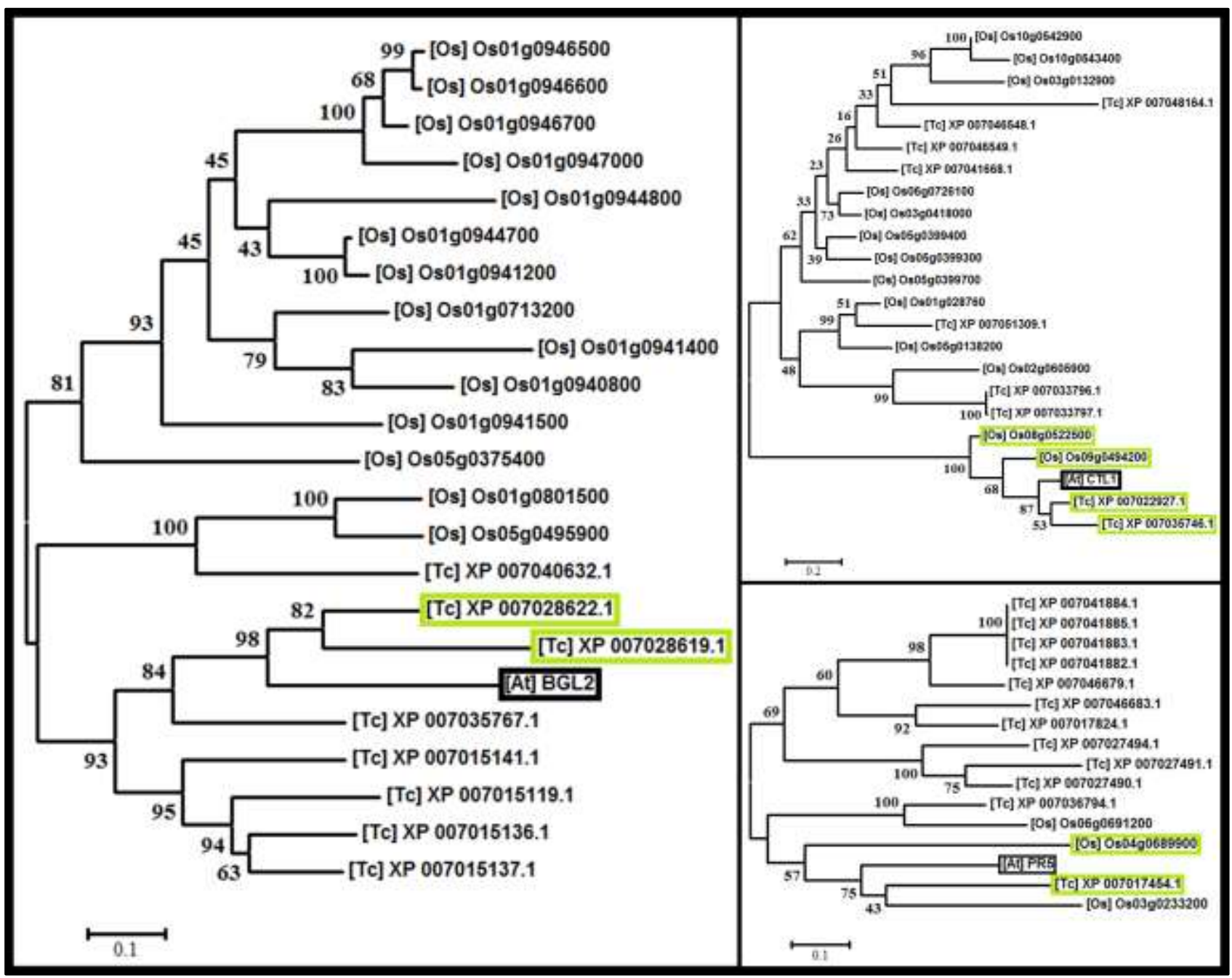

Gambar 5. Hasil konstruksi pohon filogenetik Maximum Likelihood dari setiap alignment protein menggunakan MEGA 6. A) PR-1. B) PR- 2. C) CTL1. D) PR-5. Protein A. thaliana ditandai dengan kotak hitam, sedangkan protein homolog ditandai dengan kotak hijau muda.

\section{Identifikasi Gen Homolog pada Cacao}

Genome Database. Hasil identifikasi gen homolog masing-masing gen resistan $A$. thaliana disajikan pada Tabel 2 berikut.

Tabel 2. Hasil identifikasi gen homolog pada Cacao Genome Database.

\begin{tabular}{clcc}
\hline Nama & \multicolumn{3}{c}{ Homolog } \\
\cline { 2 - 4 } gen & Cacao & Genome & GenBan \\
{$[$ At $]$} & Database & & $\mathbf{k}$ \\
\hline
\end{tabular}

PR-1 Thecc1EG006332t1 18607284

PR-2 Thecc1EG024509t1 18598848
Thecc1EG024514t1 18598851

Thecc1EG026942t1 18595074

CTL1

Thecc1EG021326t1 18603612

PR-5 Thecc1EG033984t1 18591335

\section{PEMBAHASAN}

Gen homolog pada penelitian ini ditentukan berdasarkan tingkat homologi

Analisa "In Silico" Gen Kakao (Theobroma cacao L.) yang Terlibat dalam Sistem Ketahanan Terhadap Hama dan Penyakit (Muhammad Budi Agung dkk) 
dari protein yang akan disandi gen tersebut. Keakuratan hasil analisis homologi tersebut sangat dipengaruhi oleh ketersediaan informasi pada database serta tingkat akurasi dari program yang digunakan.

Terdapat homolog postitif dan semi-homolog pada penelitian ini. Homolog positif didefinisikan sebagai homolog yang keseluruhan karakteristik dari protein tersebut cocok dengan karakteristik yang diperoleh pada database. Sedangkan semi-homolog didefinisikan sebagai homolog yang karakteristik proteinnya memiliki perbedaan dengan karakteristik yang diperoleh pada database.

Protein homolog PR-1 (XP_007041422.1), (XP_007028619.1 dan XP_007028622.1), dan PR-5 (XP_007017454.1) adalah protein yang tergolong sebagai positif homolog, sedangkan protein homolog CTL1 (XP_007022927.1 dan XP_007035746.1) tergolong sebagai semihomolog. Hal tersebut disebabkan hasil identifikasi motif pada kedua protein tersebut menunjukkan perbedaan residu pada kedua motif (CHITINASE_19_1 dan CHITINASE 19_2), seperti yang terjadi pada protein CTL1 A. thaliana (ditunjukkan pada Gambar 6), namun diduga masih memiliki fungsi yang sama dengan protein chitinase lainnya.

Protein XP_007008873.1 tergolong dalam famili protein "Cysteine-rich Secretory Protein, Allergen V5/TPX-1related", memiliki domain CAP (Cysteinerich secretory proteins, Antigen 5, and Pathogenesis Related-1 proteins) (IPR001283), serta memiliki motif “CRISP 1", “CRISP 2", “CRISP 3", dan “CRISP 4" yang terdapat pada protein PR1 A. thaliana, namun memiliki 4 domain lain (ditunjukkan pada Gambar 7), yaitu "Concanavalin A-like lectin/glucanase domain” (IPR013320), "Protein Kinase-like domain" (IPR011009), "Protein kinase domain" (IPR000719), dan "Serine/Threonine/Dual Specificity protein kinase, Catalytic domain" (IPR002290). Dari hal tersebut disimpulkan bahwa protein "[Tc] XP_007008873.1” kemungkinan fungsinya berbeda dengan PR-1 Arabidopsis thaliana karena memiliki domain lain selain domain CAP.

$$
\text { Dari hasil penelitian ini }
$$

disimpulkan bahwa gen

Thecc1EG006332t1 (homolog PR-1),

Thecc1EG024509t1 (homolog PR-2),

Thecc1EG024514t1 (homolog PR-2),

Thecc1EG026942t1 (homolog CTL1),

Thecc1EG021326t1 (homolog CTL1), dan Thecc1EG033984t1 (homolog PR-5) 
pada Cacao Genome Database (CGD) adalah gen Theobroma cacao yang homolog dengan gen yang terlibat dalam sistem ketahanan tumbuhan terhadap hama dan penyakit, serta kemungkinan besar memiliki fungsi yang sama dengan gen homolognya masing-masing.

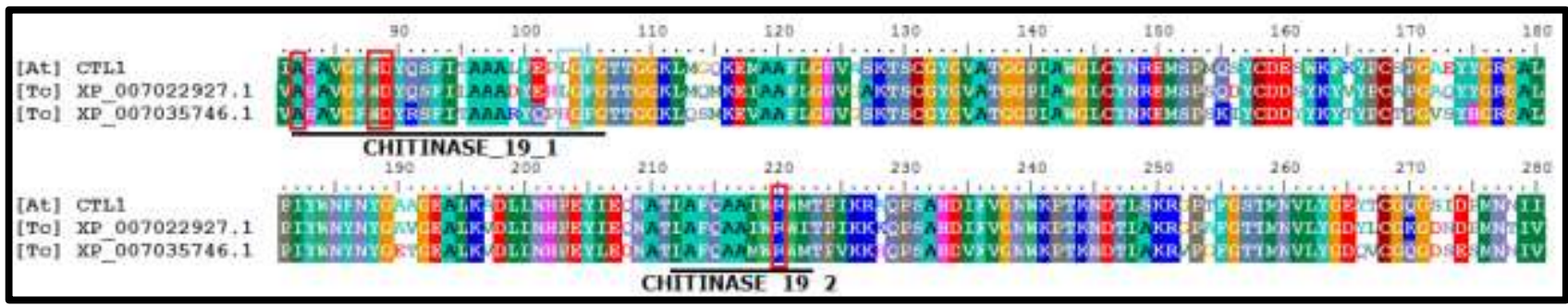

Gambar 6. Perbedaan urutan asam amino protein CTL1 Arabidopsis thaliana dan homolognya terhadap motif protein chitinase. Daerah motif protein CTL1 (CHITINASE_19_1 dan CHITINASE_19_2) ditandai dengan garis berwarna hitam. Perbedaan residu yang ditunjukkan dalam kotak berwarna merah dan dugaan insertion residu yang ditandai dengan kotak berwarna biru

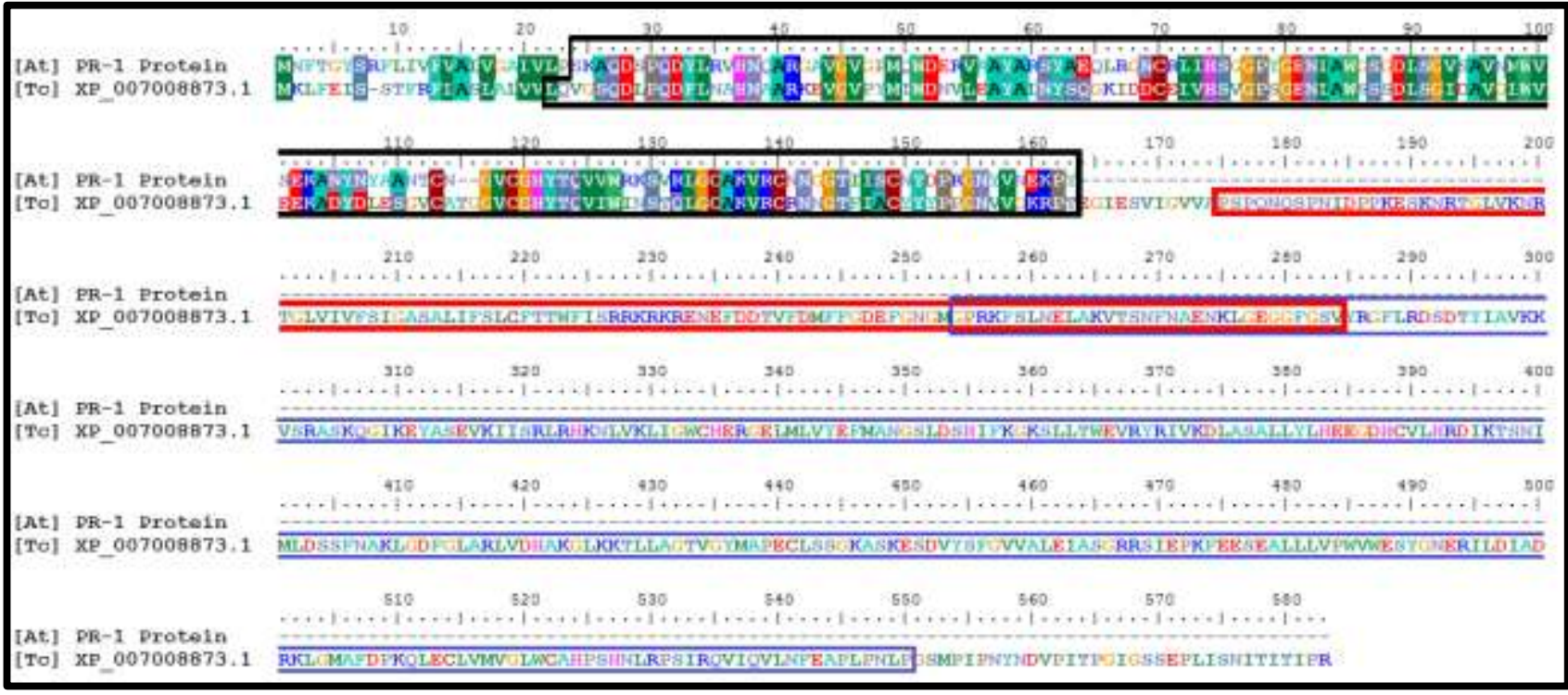

Gambar 7. Perbedaan karakteristik domain pada protein PR-1 A. thaliana dengan protein XP_007008873.1. Protein A. thaliana ditandai dengan awalan nama "[At]" dan T. cacao ditandai dengan awalan nama "[Tc]". Kotak berwarna hitam menunjukkan domain CAP (Cysteine-rich secretory proteins, Antigen 5, and Pathogenesis Related-1 proteins), kotak berwarna merah menunjukkan domain "Concanavalin A-like lectin/glucanase domain", dan kotak berwarna biru menunjukkan domain "Protein Kinase-like domain"; "Protein kinase domain"; dan "Serine/Threonine/Dual Specificity protein kinase, Catalytic domain".

\section{DAFTAR PUSTAKA}

Abad, L. R., D’Urzo, M. P., Liu, D., Narasimhan, M. L., Reuveni, M., Zhu, J. K., et al., 1996, Antifungal
Activity of Tobacco Osmotin has Specificity and Involves Plasma Membrane Permeabilization, Plant Science, 118:11-23.

\section{Analisa "In Silico" Gen Kakao (Theobroma cacao L.) yang Terlibat dalam Sistem Ketahanan Terhadap Hama dan Penyakit \\ (Muhammad Budi Agung dkk)}


Adams, D. J., 2004, Fungal Cell Wall Chitinases and Glucanases, Microbiology, 150(7):2029-2035.

Alexander, D., Goodman, R. M., GutRella, M., Glascock, C., Weymann, K., Friedrich, L., et al., 1993, Increased Tolerance to Two Oomycete Pathogens in Transgenic Tobacco Expressing PathogenesisRelated Protein 1a, Proc. Natl. Acad. Sci. USA, 90(15):7327-7331.

Altschul, S. F., Gish, W., Miller, W., Eugene W. Myers, dan Lipman, D. J., 1990, Basic Local Alignment Search Tool, J. Mol. Biol., 215:403-410.

Baker, B., Zambryski, P., Staskawicz, B., dan Dinesh-Kumar, S. P., 1997, Signaling in Plant-Microbe Interactions, Science, 276(5313):726-733.

Bartnicki-Garcia, S., 1968, Cell Wall Chemistry, Morphogenesis, and Taxonomy of Fungi, Annual Review of Microbiology, 22:87-108.

Boller, T., Gehri, A., Mauch, F., dan Vögeli, U., 1983, Chitinase in Bean Leaves: Induction by Ethylene, Purification, Properties, and Possible Function, Planta, 157(1):22-31.

Claverie, J. M., dan Notredame, C., 2007, Bioinformatics for Dummies, Edisi Kedua, Wiley Publishing, Inc., Hoboken.

Cudjoe, T., 2013, Integrated Management of Cocoa Pests and Pathogens in Africa-Controlling Indigenous Pests and Diseases and Preventing the Introduction of Exogenous Ones, Regional Workshop on Integrated Management of Cocoa Pests and Pathogens in Africa. CFC/ICCO/COCOBOD.
Ebrahim, S., Usha, K., \& Singh, B. (2011). Pathogenesis Related (PR) Proteins in Plant Defense. In A. Méndez-Vilas (Ed.), Science Against Microbial Pathogens: Communicating Current Research and Technological Advances (pp. 1043-1054). FORMATEX.

Gibbs, G. M., Roelants, K., dan O'Bryan, M. K., 2008, The CAP Superfamily: Cysteine-Rich Secretory Proteins, Antigen 5, and Pathogenesis-Related 1 Proteins-Roles in Reproduction, Cancer, and Immune Defense, Endocrine Reviews, 29(7):865-897.

Hall, T. A., 1999, BioEdit: A UserFriendly Biological Sequence Alignment Editor and Analysis Program for Windows 95/98/NT, Nucleic Acids Symposium Series, 41:95-98.

Ham, K.-S., Kauffmann, S., Albersheim, P., dan Darvill, A. G., 1991, Hostpathogen interactions XXXIX. A Soybean Pathogenesis-Related Protein with $\beta$-1,3-Glucanase Activity Releases Phytoalexin Elicitor-Active Heat-Stable Fragments from Fungal Walls, Molecular Plant-Microbe Interactions, 4(6):545-52.

Henikoff, S., dan Henikoff, J. G., 1992, Amino Acid Substitution Matrices from Protein Blocks, Proc. Natl. Acad. Sci. USA, 89(22):1091510919.

Hsing, M., dan Cherkasov, A., 2008, Indel PDB: A Database of Structural Insertions and Deletions Derived from Sequence Alignments of Closely Related Proteins, BMC Bioinformatics, 9:293.

Keen, N. T., dan Yoshikawa, M., 1983, $\beta$ 1,3-Endoglucanase from Soybean Releases Elicitor-Active 
Carbohydrates from Fungus Cell Walls, Plant Physiology, 71:460-465.

Kitajima, S., dan Sato, F., 1999, Plant Pathogenesis-Related Proteins: Molecular Mechanisms of Gene Expression and Protein Function, Journal of Biochemistry, 125(1):1-8.

Klarzynski, O., Plesse, B., Joubert, J.-M., Yvin, J.-C., Kopp, M., Kloareg, B., dan Fritig, B., 2000, Linear $\beta-1,3$ Glucans Are Elicitors of Defense Responses in Tobacco, Plant Physiology, 124:1027-1037.

Koiwa, H., Kato, H., Nakatsu, T., Oda, J., Yamada, Y., dan Sato, F., 1997, Purification and Characterization of Tobacco Pathogenesis-Related Protein PR-5d, an Antifungal Thaumatin-like Protein, Plant Cell Physiol., 38(7):783-791.

Motamayor, J. C., Mockaitis, K., Schmutz, J., Haiminen, N., Iii, D. L., Cornejo, O., et al., 2013, The Genome Sequence of the Most Widely Cultivated Cacao Type and its Use to Identify Candidate Genes Regulating Pod Color, Genome Biology, 14:53.

Niderman, T., Genetet, I., Bruyère, T., Gees, R., Stintzi, A., Legrand, M., et al., 1995, Pathogenesis-Related PR-1 Proteins Are Antifungal, Plant Physiology, 108:17-27.

Parker, J. E., Holub, E. B., Frost, L. N., Falk, A., Gunn, N. D., dan Daniels, M. . J., 1996, Characterization of EDS1, a Mutation in Arabidopsis Suppressing Resistance to Peronospora parasitica Specified by Several Different RPP Genes, The Plant Cell, 8(11):2033-2046.

Quevillon, E., Silventoinen, V., Pillai, S., Harte, N., Mulder, N., Apweiler, R., dan Lopez, R., 2005, InterProScan:
Protein Domains Identifier, Nucleic Acids Research, 33:116-120.

Reymond, P., dan Farmer, E. E., 1998, Jasmonate and Salicylate as Global Signals for Defense Gene Expression, Current Opinion in Plant Biology, 1(5):404-411.

Rivière, M.-P., Marais, A., Ponchet, M., Willats, W., dan Galiana, E., 2008, Silencing of Acidic PathogenesisRelated PR-1 Genes Increases Extracellular $\beta$-(1 $\rightarrow$ 3)-Glucanase Activity at the Onset of Tobacco Defence Reactions, Journal of Experimental Botany, 59(6):12251239.

Ryals, J. A., Neuenschwander, U. H., Willits, M. G., Molina, A., Steiner, H.-Y., dan Hunt, M. D., 1996, Systemic Acquired Resistance, The Plant Cell, 8:1809-1819.

Sela-Buurlage, M. B., Ponstein, A. S., Bres-Vloemans, S. A., Melchers, L. S., Van Den Elzen, P. J. M., dan Cornelissen, B. J. C., 1993, Only Specific Tobacco (Nicotiana tabacum) Chitinases and $\beta-1,3-$ Glucanases Exhibit Antifungal Activity, Plant Physiology, 101(3):857-863.

Tamura, K., Stecher, G., Peterson, D., Filipski, A., dan Kumar, S., 2013, MEGA6: Molecular Evolutionary Genetics Analysis Version 6.0, Molecular Biology and Evolution, 30(12):2725-2729.

Van Loon, L. C., Rep, M., dan Pieterse, C. M. J., 2006, Significance of Inducible Defense-Related Proteins in Infected Plants, Annual Review of Phytopathology, 44:135-162.

Wessels, J. G. H., dan Sietsma, J. H., 1981, Fungal Cell Walls: A Survey, 
dalam W. Tanner dan F. Loewus (Eds.), Encyclopedia of Plant Physiology (Vol. 138, pp. 352-394), Springer Berlin Heidelberg, Berlin.

Woloshuk, C. P., Meulenhoff, J. S., SelaBuurlage, M., Van den Elzen, P. J. M., dan Cornelissen, B. J. C., 1991, Pathogen-Induced Proteins with lnhibitory Activity toward Phytophthora infestans, The Plant Cell, 3:619-628.

Yeh, S., Moffatt, B. A., Griffith, M., Xiong, F., Yang, D. S. C., Wiseman, S. B., et al., 2000, Chitinase Genes Responsive to Cold Encode Antifreeze Proteins in Winter Cereals, Plant Physiology, 124(3):1251-1264.

Zhang, J., Du, X., Wang, Q., Chen, X., Lv, D., Xu, K., et al., 2010, Expression of Pathogenesis Related Genes in Response to Salicylic Acid, Methyl Jasmonate and 1Aminocyclopropane-1-Carboxylic Acid in Malus hupehensis (Pamp.) Rehd, BMC Research Notes, 3:208. 